\title{
VITA - DISCUSSION
}

\section{VOLTAK-E A 10-12. SZÁZADBAN „SZÁLLÁSI” TEMETŐK?}

\author{
FODOR ISTVÁN*
}

\begin{abstract}
László Kovács has recently proposed a classification of the 10th-12th-century cemeteries of Hungary and he associated one group of burial grounds with the nomadic campsites of the ancient Hungarians. The present author challenges this view, pointing out that the greater part of the ancient Hungarian population did not pursue a nomadic life-style at the time of the Conquest (895) and that hydrological conditions in the Carpathian Basin made any eastern-type nomadism impossible. Thus, the still nomadic groups of the ancient Hungarian population too became sedentary during the 10th century, meaning that the name given to the cemeteries in question is erroneous.
\end{abstract}

Keywords: Nomadic campsites, cemeteries of the middle social class of the ancient Hungarians, extended families, nuclear families

A 10-12. századi magyar temetők osztályozását kísérelte meg nemrég Kovács László. A vizsgált temetók egyik csoportját a magyar nomád szállások temetőinek nevezte. A szerző ezt az elgondolást birálja, rámutatva, hogy a magyarság jelentôs része már a honfoglalás idején (895) sem volt nomád, és a Kárpát-medence egykori vizrajzi viszonyai miatt itt alig lehetett keleti módon nomadizálni. Ezért a 10. században a még nomád magyar csoportok többsége is megtelepült. A szerzö nem tartja helytállónak a temetötípus elnevezését.

Kulcsszavak: nomád szállások, a magyar középréteg temetői, nemzetség, nagycsaládok, kiscsaládok

A Kovács László 70. születésnapjára készült igen testes (885 oldalas) kötetben az ünnepelt két nagy terjedelmú dolgozattal lepte meg - elsősorban nem saját magát, hanem a kötetet forgató szakembereket. Ezek egyike „A Kárpát-medence honfoglalás és kora Árpád-kori szállási és falusi temetői. Kitekintéssel az előzményekre" címü, 94 oldalas tanulmány, amelyet szerzője szerényen csak vázlatnak nevez, pedig valójában igen alapos és gondolatébresztó elemzés. Tárgya a hon-

* A kézirat érkezett: 2015. május 14.

* Fodor István. Magyar Nemzeti Múzeum, 1088 Budapest, Múzeum krt.14-16.; istvan.fodor@t-email.hu foglalás és kora Árpád-kori szállási és falusi temetők áttekintése és javaslat a csoportosításukra. ${ }^{1}$ Azt hiszem, nem én vagyok az egyetlen, aki kissé értetlenül nézegette a címet, hiszen az még csak világos, hogy mik azok a falusi temetók, de az már fogas kérdés, mit kell értenünk ebben a korban a „,szállásinak" nevezett temetők alatt.

Maga a szállás szó sem igen ismeretes ma már az egész magyar nyelvterületen „település, lakóház" értelemben. Györffy István a magyar tanyáról írott dolgozatát így kezdte: „A tanya, vagy ré-

KovÁCS 2013 
gebbi nevén szállás...". ${ }^{2}$ Alább - egy másik értelmét adva meg a szónak - így folytatta: „A kültelki ideiglenes emberi telep régi magyar neve szállás, amit az oklevelek descensusszal adnak vissza." 3 Etimológiai szótárunk a szó írott formában való előfordulását 1211-től ismeri, és megjegyzi, hogy a magyarból elterjedt a románban, oszmán-törökben és több szláv nyelvben is, továbbá, hogy származékszó a száll igéből. ${ }^{4}$ Az értelmező szótárból többek között azt is megtudhatjuk, hogy ez a szó még ma is használatos az Alföld déli részén, fóként a ma Szerbiához tartozó Délvidéken. ${ }^{5}$ (Elsősorban „állandóan vagy ideiglenesen lakott tanya" jelentésben.) Mindehhez még hozzá kell vennünk, hogy népünk a régiségben így nevezte a nomádok téli és nyári szállásait is, amit máig csak a tudomány nyelve örzött meg.

Elöljáróban szeretném még megjegyezni, hogy a szerző által javasolt "szállási temetők" terminus eleve nem túnik túlságosan szerencsésnek. Mert a Délvidéken ugyan vannak szállási (tanyasi) tojások meg rántani való csirkék, de szállási temetőket soha nem emlegetnek.

Nyilvánvaló azonban, hogy Kovács László ezt a - szerinte leggyakoribb, száz sírnál kevesebbet számláló - temetőtípust az egykori nomád szállások temetőinek gondolja, mivel ekkor még élőnek véli honfoglalóink nomád állattartó gazdálkodását, majd a korai Árpád-korban idesorolja a praediumszerú kis települések temetőit is. Csakhogy az Árpád-korban már vannak hasonló elnevezésú temetőink, mégpedig a kun szállástemetók. A nomád kunok egy részének az Alföldre való betelepítésével a tatárjárás után újfajta települések jöttek létre, a nomád és megtelepülő kunok szállásai, amelyek valóban a keleti nomád szállásokra, nem pedig a magyar falvakra hasonlítottak. Ezt a különbséget érzékeltette a kétféle elnevezés. A kunok lakta vidékeken sorra túntek fel ezek a „szállások": Asszonyszállás, Ködszállás (Karcag mellett). Ezt a nevet kapták azok a korábbi magyar falvak is, ahol a jövevény kunok megtelepedtek - így például Kengyel neve Kengyelszállásra változott. ${ }^{6}$ Ezek után magától adódik a kérdés: nevezhetnénk-e ezt a temetótípust kun mintára magyar szállástemetőknek? Magam úgy vélem, ez csak akkor lenne helyénvaló megoldás, ha a 10-11. századi magyarok és a 13-14. századi kunok gazdálkodása és telepü-

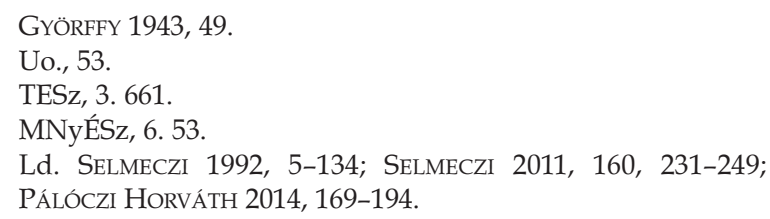

léseik arculata nagyon hasonló képet mutatna. Lássuk, helytálló-e egy efféle feltevés.

Kovács László csak érintőlegesen tér ki a honfoglaló magyarság gazdálkodásának még legfontosabb kérdéseire is. Ugyan azt ígéri, hogy megkísérli majd a szállások és a falvak szembeállításával megmagyarázni a két temetőtípus („,szállási” és „falusi”) közti különbséget.7 Ezek után azt várhattuk volna, hogy a hazai és nemzetközi szakirodalom, valamint a régészet tanulságai alapján felvázolja honfoglalóink gazdálkodásának helyzetét a honfoglalást megelőző egy-két évszázadban, illetve a 10. században a Kárpát-medencében történt alapvető változásokat. Ehelyett meglepve látjuk, hogy a szerző a nomádok és a nomadizmus lényegének és történetének legalapvetőbb szakirodalmát sem használja. (Például G. E. Markov és A. M. Khazanov monográfiáit, Sz. I. Rudenko nálunk is megjelent, nagy összegző tanulmányát, továbbá Tagán Galimdzsán és Ali Khan Ibrahim magyar nyelvú munkáit.) Ehelyett beéri a Kristó Gyula által kiadott Kora középkori történeti lexikon szócikkeivel, amelyek színvonala ugyan változatos, de magasnak semmiképpen nem nevezhető. Olvashatunk itt a nomadizáló magyar falvakról, amelyeknek Szent László és Kálmán törvényekkel tiltotta meg, hogy a templomtól messzire költözzenek. De hát itt korántsem erről volt szó, hanem arról, hogy a földeket ekkor még nem trágyázták, így azok egy idő után kimerültek. Múvelőik ekkor új szántókat tettek múvelhetővé, amire még bőven volt lehetőség. A gazdálkodás pedig akkor volt a leghatékonyabb, ha a szántóvető közel lakott a földjéhez. Nem a templom vagy a pap elől menekült tehát a falu népe, hanem igyekezett jobb életfeltételeket teremteni azzal, hogy lassú mozgású igavonó ökreivel ne kelljen fél napot az odaés visszaútra fordítania.

Tudomást szerzünk továbbá a temetó körül köröző faluról, a már lanyhuló nomád legeltetésról, amikor már nem mindenki vonul az állatokkal, a titokzatos „faluszerü" településekröl. Ezek ugyanúgy fantom fogalmak, mint a téli szálláson maradó és a környező területet trágyázó kezes állatok, hiszen ha ezek a jámbor jószágok lelegelték volna a szállás környéki mezőket, a nyár végén a nyári szállásról visszatérő csorda alighanem jórészt éhen pusztult volna télen. ${ }^{8}$ Ugyanitt említi meg a szerző, hogy azért elfogadhatatlan László Gyula ötlete a Budapest környéki magányos sírokról és kis temetőkról (miszerint azok a téli-nyári szállásváltás következtében alakultak

\footnotetext{
KovÁcs 2013, 519.

8 Uo., 519-520.
} 
volna ki) ${ }^{9}$ mert a honfoglaló magyaroknál nem igazolható e két szállás egykori léte. Tudna a szerző egyetlen esetet is említeni, amikor bárhol sikerült volna régészetileg egyértelmúen azonosítani a nyári szállás helyét?

A szövegből úgy látom, hogy szerzőjének az a hiedelme, miszerint a nomádok mindig ott temették el a halottaikat, ahol éppen legeltettek. Ez azonban nem így van. ${ }^{10}$ A nomád közösségeknek legtöbbször csak egy temetőjük volt, bár ez a legelőváltó út hosszától függött. (Például Kazahsztánban ${ }^{11}$ és Turkesztánban ${ }^{12}$ a két szállás közti út gyakran az ezer kilométert is meghaladta, ami kizárta, hogy halottaikat egy helyen temessék el.) Ezzel szemben az Alföldön a folyókra merőlegesen nomadizáló honfoglaló közösségek esetében ez az út többnyire nem haladta meg a 10-30 kilométert, ${ }^{13}$ ezért gyakorlatilag csak egy szállásuk (és egy temetőjük) volt, a folyóhoz közeli háton lévő téli szállás, amely viszonylag rövid idő alatt állandó településsé vált. A nomadizmus keleti formáját (a folyók menti legelőváltást) ugyanis, amelyet elődeink még Levédiában és Etelközben is folytattak, ${ }^{14}$ a folyószabályozás előtti Kárpát-medencében lehetetlen volt gyakorolni az óriási árvizes és mocsaras területek miatt. Ezért még nomadizáló őseink a Kis- és Nagyalföldön a folyóra merólegesen létesítettek legeltető utat. Téli szállásuk egy magasabb háton volt, és amikor nyáron az itteni legelő kiszáradt, állataikat a folyó melletti ártérre terelték, ahol a zöldár levonulása után szinte napok alatt dús fú nőtt a területen. A két szállás közelsége miatt a nyári legelőkre nem költözött át az egész lakosság, a téli szállás pedig hamarosan állandó faluvá rögzült. Ehhez hozzá kell még vennünk, hogy a honfoglalók jelentős része már nem nomádként, hanem megtelepedett falulakóként érkezett a Kárpát-medencébe. Megtelepedésük folyamata Kelet-Európában zajlott le a 8-9. században. Ezért alakult ki viszonylag gyorsan - még a 10. században - a települések százait magában foglaló magyar faluhálózat és a szolgáltató falvak

9 A téli és nyári szállások temetői közti különbséget később Csalog Zsolt igyekezett kimutatni a sírok eltérő tájolása alapján; ld. Csalog 1967 és Csalog 1969. Csalog úgy vélte, hogy a 10-11. században a magyarság négyötöde még a téli és nyári szállás között nomadizált. Ezt az abszurd feltevést cáfolta nyomós érvekkel: DiENEs 1974. A Csalogéhoz hasonló ötletek fölött mára végleg eljárt az idő.

10 A nomádok általában minden időben a téli szállás mellett létesítettek temetőt; ld. SILOV 1975, 79.

11 Fielsztrup 1927, 81-85; POLjaKov 1980, 45.

12 Ali Khan 1930, 14.

13 Vizsgálataival Csalog Zsolt is arra a következtetésre jutott, hogy a téli és nyári szállás igen közel volt egymáshoz; ld. CSALOG 1967, 237.

14 Vö. GYÖRFFY 1970, 193. rendszere, ami lehetóvé tette az európai életmódhoz való lassú idomulást, végső soron a keresztény, húbéri magyar állam kialakítását. A nomád életforma zömmel csak a nagy tájegységek (alföld és hegyvidék) találkozásánál élhetett tovább, ahol - a Mátraalján - Györffy István meg is találta a párhuzamos névadású nomád szállások neveit. ${ }^{15}$

Milyen volt ezzel szemben a 13. századi kunok gazdálkodása? A 11. század közepén a kunok Belső-Ázsia, Turkesztán és a Kaspi-vidék kietlen, száraz és félsivatagos területéról érkeztek Európa keleti peremére. A Volgán 1055-ben keltek át. A legeltetó-állattartó népeknek ahhoz a csoportjához tartoztak, akiket „szélsőséges" nomádoknak nevez a kutatók egy része, mintha erről ők maguk tehettek volna. A valóban szélsőséges életföldrajzi környezet formálta gazdálkodásukat, amelyben a földmúvelésnek, a megtelepült gazdálkodásnak alig jutott szerep. A nomád állattartásnak viszont mesterei voltak. Megéltek, ha nem is a jég hátán, de a semmivel sem kellemesebb forró félsivatagban is. Évszázadok hagyományait folytatták a valamivel már csapadékosabb, kevésbé zord kelet-európai sztyeppéken. Hiába vallatják régészek százai a szemhatár széléig terjeszkedő pusztaságokat, hagyatékukból csak a temetkezéseket találják. Pedig ők is csak laktak valahol. Igen, de zömmel a Radziviłł-kódexben látható kalyibákban, sátoros szekereken és magukban a nemezsátrakban. Nyomot hagyó épületeik alig voltak. (Nem úgy, mint a jóval korábban nagyjából ugyanitt élő szkítáknak, akiknek egyik téli szállásuk, a Dnyeper torkolatánál fekvó Kamenszkoje gorodiscse valóságos ókori város volt. Ez is jól szemlélteti az egyes nomád népek közti különbségeket, amit az elméleti tudós kutató sokszor nem is érzékel, egy kalap alá véve a nomád életforma ezernyi változatát.) Alig ismerjük egy-két téli szállásuk csekély emléket hagyó nyomát.

Majdnem ugyanígy érkeztek hazánkba a kunok is a tatárjárás előestéjén, majd azt követóen újra. Nem csoda, hogy sokkot okoztak a magyar falvak lakóinak, akik bizonyára megvetették a szemükben erőszakos, primitív hordát. Az idő múlásával azonban a kunok is idomultak a körülményekhez. Keleti módon ők sem tudtak legeltetni, ezt az említett természeti körülmények sem tettek lehetóvé, a szabad legeltetésben pedig a magyar falvak vetései is akadályozták őket. ${ }^{16}$ Keleti mintára létrehozott szállásaik lassan megszilárdultak, belesimultak a környezetbe.

15 Ezekről a kérdésekről összefoglalóan ld. korábbi tanulmányaimat: FODOR 2002; FODOR 2006; FODOR 2014, további bőséges irodalommal.

16 FODOR 2013, további irodalommal. 
Mindez mégis azt jelenti, hogy a megtelepedés jóval előrehaladottabb fokán álló honfoglalók és a 13. századi kunok hajlékai és települései semmiképpen nem ítélhetók még közel azonosnak sem. Indokolatlan tehát a korai magyar településeket szállásoknak tartani, nyugvóhelyeiket pedig szállástemetőknek.

Lássuk ezek után, mi volt a véleménye a korai magyar és kun településekról Szabó Istvánnak, a magyar középkori településtörténet kiváló tudósának. „Azok az egykorú - főleg arab, perzsa és görög - források, melyek írói a lebediai és etelközi földeken élő magyarokról a 9-10. századokban először vettek tudomást, a nagy sztyeppe nomád népeinek jellegzetes vonásait örökítették meg rajtuk. [...] Gazdasági viszonyaik, társadalmi szerkezetük, politikai szervezetük, harcmodoruk és életmódjuk általában közös volt a sztyeppe más, régebbi és újabb népeivel. [...] A Duna-Tisza vidékén alig egy század múlva, az egyelőre gyér, de majd egyre bővebben fakadó írott történeti források, nevezetesen törvények, oklevelek, krónikai múvek, valamint a régészeti emlékek tükrében a magyarok már lényegesen más képet mutatnak: falvak - éspedig az állandó letelepedettség jegyét hordó falvak - lakói, s a falvakban házakban élnek, mintha a nomádsághoz nem lenne már közük. A 11. századi törvények - mint I. István decretumai is - az együtt élő kisebb közösségek lakóhelyeként következetesen faluról (villa) szólnak. Még a többé-kevésbé faluszerú descensusokról, illetőleg a megfelelő magyar szállásról sincs szó e forrásokban, holott a nomádságnak - vagy akárcsak hagyományainak is - inkább ez utóbbi felelne meg. Utóbb, a 13. század derekán Magyarországra telepedett kunoknak valóban egy-két századon át nem annyira falvait, mint inkább a faluszerüség mellett is a nomád állapotra utaló szállásait emlegetik." Majd a lábjegyzetben, Kniezsa Istvánra hivatkozva Szabó István megjegyzi: „A szállás utótagú helységnevek, miként a falva, háza, földje stb. utótagok is, csak a 13. században jelennek meg." 17

A fentiek alapján számomra egyértelmü, hogy a Kovács László által elkülönített temetőtípust minden szempontból indokolatlan szállás-, fóként pedig „szállási" temetönek nevezni. Ezzel le is zárhatnám dolgozatomat, ám nem mehetek el szó nélkül a szerző e temetőkhöz fúzött, túlságosan is bőséges kommentárjai mellett, amelyek a valószínútlenül apró betúkkel szedett lábjegyzeteket dagasztják hatalmas terjedelmúvé.

A szerző hosszasan tárgyalja a László Gyula által elkülönített nagycsaládi temetők szerte-

17 SZABÓ 1966, 7. ágazó problémáit. ${ }^{18}$ Részletesen ismerteti Bóna István hipotézisét, amely szerint e kis sírszámú temetők a 10. század első harmadában zömmel a vikingekéhez hasonló katonai őrhelyek temetói lettek volna. ${ }^{19} \mathrm{Ez}$ a feltevés valóban megfontolandó lehet azon temetők esetében, ahol jelentős a fegyveres férfisírok túlsúlya. Két körülmény azonban mindenképpen ellene szól. Az egyik az, hogy a honfoglalók sztyeppei nomád hagyományokon nyugvó hadszervezetének lényegében semmi köze a vikingekéhez, másrészt pedig a viking táborokhoz olyan építmények is tartoztak, amelyeknek nálunk nyomát sem találjuk. ${ }^{20}$

A szerző mérlegeli annak lehetőségét is, hogy e temetőtípus nem mindegyik nyugvóhelyét nyitották a honfoglalás után, mivel Dienes István 1986-ban - igaz, minden bizonyítási kísérlet nélkül - felvetette, hogy a Kárpát-medencében már az első kalandozó nyugati hadjárat, tehát 862 után megtelepedhettek magyar népcsoportok. ${ }^{21}$ Ezt a lehetőséget azóta is számosan felvetették, többnyire dilettánsok, de a kérdésben kevésbé járatos szakemberek is. Bizonyítani azonban ők sem kísérelték meg, mivel ez az ötlet egyelőre bizonyíthatatlan. Nem valószínú ugyanis, hogy a nyugati és bizánci források egyaránt elhallgatták volna a keletről jött harcias népnek ezt a nem jelentéktelen lépését. Régészeti nyomai sincsenek egyelőre e korai megtelepedésnek.

Természetesen hosszas vizsgálat tárgyát képezi a honfoglalás kori magyar nagycsalád. A szerző - sajnálatos módon - megfeledkezik arról, hogy legalább fó vonásaiban meghatározza e családtípus mibenlétét, és felvázolja történeti útját. Pedig nem ártott volna, mert a kérdés körül számos legenda terjed a kutatásban.

A nagycsalád tulajdonképpen gazdasági célú társulás, amely csak apai ágon jelent vérrokonságot. A családfő házaspárt, felnőtt fiúgyermekeiket és menyeiket, valamint ezek gyermekeit foglalja magában; létszáma nagyjából 15-30 főre rúgott, és általában három-négy nemzedéken át éltek együtt. A nagycsalád feje a legidősebb férfi (néha azonban nó is lehet), ô felügyeli a család életét, osztja el és irányítja a közös munkát. Ez a családforma kimutatható legalábbis a rézkor óta szinte a jelenkorig (nálunk például a szlavóniai magyarságnál). A középkorban a telkes jobbágyok körében terjedt el leginkább, amikor a célszerú gazdálkodás mellett bizonyos adóterhek elkerülését is elősegítette. Hibás vélekedés szerint a balkáni délszláv zadruga terjedt át valami-

\footnotetext{
18 KovÁcs 2013, 520-527.

19 BÓNA 1997a, 1458-1459.

20 Brøndsted 1983, 15A kép.

21 KovÁCs 2013, 521-522.
} 
kor a magyar nyelvterületre. Ez azonban bizonyíthatóan nem így történt. ${ }^{22}$ Öseinknél a nagycsaládi rendszer már a Kr. e. II. évezredtől megfigyelhető, ${ }^{23}$ de a bronzkortól számos más népnél is kimutatható - például a korai nomád szkítáknál ${ }^{24}$-, mindig a mai értelemben vett kiscsaládi szervezettel együtt.

A régészeti kutatások szempontjából igen lényeges, hogy a nagycsaládnak melyek azok a jellemvonásai, amelyeket régészeti módszerekkel is vizsgálni lehet. Nézetem szerint egyetlen ilyen jellegzetessége van, mégpedig az, hogy közös lakóépületben élnek. Ez jellemző a bronzkortól kezdve ${ }^{25}$ egészen a $15-16$. századig, ${ }^{26}$ sót a közelmúltig. ${ }^{27}$ A néprajzi megfigyelések azt is igazolják, hogy ez a nomád népeknél is így volt, ${ }^{28}$ csakhogy a nemezjurtának nem maradt nyoma a földben, ezért régészetileg nem kutatható.

A kutatók egy része feltételezte, hogy az eurázsiai nomádok körében a nagycsaládi rendszer volt a jellemző, ${ }^{29}$ ám ezt nem lehet igazolni. Annál kevésbé, mivel a nomadizmusnak is számos, többé-kevésbé eltérő változata létezik. Mindenesetre az látszik valószínúnek, hogy az úgynevezett "tiszta” nomádok körében inkább a kiscsaládi rendszer volt a gyakoribb. Több ilyen család alkotta a nomád falut, az ault. A nomád legeltetés aulok szerint folyt. ${ }^{30} \mathrm{~A}$ földmúveléssel intenzívebben foglalkozó félnomádok körében a nagycsaládi rendszer volt elterjedtebb. ${ }^{31} \mathrm{~A}$ korábban általánosan elfogadott feltevés szerint a nomadizmus visszaszorulásával, a 10-12. század körül a nagycsaládi rendszer elavulttá vált, és lassanként elhalt. Ezzel szemben - például a magyarságnál is - azt látjuk, hogy a feudalizmusban újabb virágkorát élte. ${ }^{32}$

Elmélete kidolgozásakor László Gyula azt feltételezte, hogy a honfoglalás kori nagycsaládok külön temetőbe temetkeztek. ${ }^{33}$ A későbbi időszakból ismert esetekben azonban a nagycsaládoknak nem volt külön temetőjük, csupán a falusi temetőn belül volt külön parcellájuk. Amikor ez a parcella megtelt, az elhunytakat a régi sírokra ásták rá. ${ }^{34}$ Fentebb azonban már láttuk, hogy a

22 Penavin 1981, 5-27; CSEH 1976.

23 Balassa-Ortutay 1979, 46-48; Szabó 1980, 29.

24 HAZANOV 1975, 74.

25 FODOR 1975, 55; FODOR 1992, 112-113; vö. SZABÓ 1980, 29-33.

26 Holl 1979, 49

27 Ld. 22. jegyzet; PENAVIN 1973, 189-190, 263.

28 HAZANOV 1975, 67-69.

29 KRADER 1963, 388-389.

30 Potapov 1966, 17-28.

31 HAZANOV 1975, 76.

32 Vö. HaZANOv 1975, 73-76; KHAZANOv 1984, 129-132.

33 LÁSZLÓ 1944, 125-225.

34 Penavin 1981, 161-164. A régi társadalmak csoportjai közül a külön temető használata nem a nagycsaládok egyik jellemző- nagycsaládok nyomát éppenséggel nem a temetókben, hanem a településeken figyelhetjük meg az őskortól a legújabb korig. 10-12. századi feltárt falvaink területén eddig még nem kerültek elő nagycsaládinak ítélhető lakóházak. László Gyula másik feltételezése az volt, hogy szerencsés esetben felismerhetó e családtípus teljes szerkezete. Ebben lényegében igaza is lett. Ahhoz azonban, hogy egy ilyen helyzet elóálljon, tényleg óriási szerencsére volt szükség. Arra, hogy egy nagycsaládban mindenki „szabályosan” haljon meg, ne az öregebb családtagok túl fiatalon, de ne is a fiatalabb nemzedék túl öregen. Emellett még olyan temetót is ki kellett fogni, ahová nagyjából csak egy nemzedék temetkezett. Ilyen temető előkerülésének azonban rendkívül kicsi az esélye. László Gyulának mégis sikerült ilyenre akadnia, amelyból nagyjában-egészében ki is bontotta egy nagycsalád fó jellemvonásait. A Jósa András felügyelete mellett feltárt tiszabezdédi temetőről van szó, ahová feltehetően valóban egy nagycsalád egyetlen nemzedéke temetkezett. Ehhez még távoli analógiát is találunk a hasonló korú votjákföldi midlany-sáji temetőben igaz, ott hat sírsort talált Vladimir Gening, továbbá a nőket és a férfiakat külön sorokba temették. ${ }^{35}$ Nem hiszem, hogy néhány feltételezett hibás embertani meghatározás és egyéb pontatlanságok, hiányosságok miatt kétségbe kellene vonnunk a nagycsalád létét Bezdéden, sőt általában honfog-

je, hanem a nemzetségeké. V. N. Csernyecov ezt az obi-ugoroknál mutatta ki (CSERNYECOV 1949). A közelmúltban megfigyelt magyar nemzetségekre (hadakra) azonban már nem volt jellemző a külön nemzetségi temető. Ők is csupán külön parcellákat kaptak a falusi temetőn belül. Lásd pl. a dél-erdélyi, Vajdahunyad melletti Rákosdon, valamint a Fekete-Körös vidékén: Kós 1972; Kós 1976, 74-77. A családok és a nemzetségek (hadak) közti különbséget szemléletesen definiálja egyik néprajzi kézikönyvünk: „A kis- és nagycsalád azonos nevet viselő gazdasági egység, mely az esetek többségében azonos telken, házban él. Ezzel szemben a nemzetség, a had gazdaságilag nem tartozik együvé" (BALASSA-OrTUTAY 1979, 58). Ugyanitt a szerzők azt is megjegyzik, hogy a két fogalom között időnként nehéz különbséget tenni, mivel tartalmuk néhol átfedi egymást. Ez azonban nyilvánvalóan nem így volt a régiségben, például a honfoglalás korában. A vérrokon, patriarchális és exogám nemzetségek alkották a népet és országot egybetartó, legszívósabb társadalmi egységet, különösképpen a nomádoknál, amit az írott források is alátámasztanak. (Lásd pl. a türköknél: EcsEdy 1974.) A nemzetség jóval nagyobb volt, mint a nagycsalád, és nem volt gazdálkodási egység, így törzsek és nemzetségek nem nomadizáltak együtt (VAJNSTEJN 1972, 70, 77). Ezért valószínútlen Bóna István azon feltevése, miszerint „László Gyula valóban azt fedezte fel, amit a régi magyar nyelv - aligha véletlenül vagy indokolatlanul - „hadnak” nevezett” (BóNA 1997a, 1455). Ekkor ugyanis nálunk már rég nem voltak nemzetségi temetők, csupán a nemzetségfők családjainak, fegyveres kíséretének, szolgáló népeinek temetői.

35 FODOR 2001, 192-196, további irodalommal. 
lalóink társadalmában, amint azt Révész László tette. ${ }^{36}$ Korábban Bóna István is tévesen ítélte meg ezt a temetőt. ${ }^{37}$ Eddig a bezdédi az egyedüli bizonyítékunk arra, hogy a honfoglalás korában - szemben a középkorral és az újkorral - lehettek külön nagycsaládi temetők is. Ám ez az egyedüliség arra is rávilágít, hogy a szokás akkoriban sem lehetett általános.

Régészeinknek nem volt többször ilyen szerencséjük. Elsôsorban azért, mert a feltárt 10-11. századi sírok meglepően magas száma $(26000)^{38}$ ellenére szinte alig van néhány biztosan teljesen feltárt temetőnk. Nagyon valószínú ugyan, hogy számos nagycsaládi temetőrészlet (talán teljes temető is) napvilágra került, ezek azonban nem értékelhetók világosan. ${ }^{39}$ Kovács László messzemenően egyetért - Bóna István gondolatát ismételve - id. Fehér Gézának az ötvenes évek elején a szóban forgó temetókról tett megjegyzésével, aki szerint az ott megfigyelt nemi arány teljesen elképzelhetetlen a nagycsaládban. ${ }^{40}$ Valóban, ám ezek a sírcsoportok nem a nagycsaládok teljes (vagy csaknem teljes) nemzedékének nyugvóhelyei, így nem is reprezentálják azok létszámát és szerkezetét. Vagy túl rövid ideig használta egy közösség ezeket a nyugvóhelyeket, vagy ellenkezőleg, három-négy generáció temetkezett ide, ezért nem ismerhetők fel bennük az egyes nemzedékek sírjai.

Igaz, vannak olyan, egymáshoz közel fekvő temetőink, ahová feltehetóen egy település különféle társadalmi helyzetú csoportjai temetkeztek. Két ismert példát említek: a felvidéki Szeredet ${ }^{41}$ és Sóshartyánt. ${ }^{42}$ Nagycsaládi rendszert azonban eddig itt sem sikerült kimutatni.

Még egy megjegyzés a nagycsaládi temetőkrôl. Kovács László úgy véli, hogy mi Dienes

36 RÉvÉSz 1991; RÉvÉsz 2003. A bezdédi temető hiányos dokumentáltságának alapos elemzése feltétlenül hasznos volt, ám e hiányosságok részben csak arra utalnak, hogy a László Gyula által a nagycsaládi temetőnél elvárt törvényszerúségek (pl. a nyilak számának csökkenése a sorok vége felé) nem igazolhatók, de ez nem cáfolja a nyugvóhely nagycsaládi mivoltát. Már ha ezt a családformát helyesen értelmezzük, és nem „vérségi alapon szerveződött közösségnek” véljük (RÉvÉSZ 1991, 625).

37 Kiváló régészünk a következő megállapítást tette: „Nem léteztek tehát együtt élő vérségi nagycsaládok, vagy ha léteztek is, nem az eddig említett temetők a régészeti bizonyítékaik." Ld. BÓNA 1997a, 1455.

38 BÓNA 1997a, 1451. Csak összehasonlításképpen: néhány évvel ezelőtt az orosz régészet még csak 160 biztosan kazárnak tartható sírt ismert. Pedig ók egy nagy birodalom urai voltak.

39 A különböző társadalmi csoportok temetőkben való felismerésének nehézségeiről jó másfél évtizeddel ezelőtt Mesterházy Károly értekezett: MESTERHÁzy 1998.

40 FEHÉR 1959, 265-266.

41 TOČIK $1968,40-58$.

42 FODOR 1973, 32.
Istvánnal „,kettős módon” vélekedtünk erről a temetőtípusról, illetóleg a honfoglalás kori nagycsaládokról. Mégpedig azért, mert miközben a kiscsaládok túlsúlyát véltük jellemzőnek a korra, nem tagadtuk a nagycsaládok egykori létét sem. ${ }^{43}$ (Mint ahogyan most Kovács László teszi, Bóna István véleményéhez csatlakozva.) Valóban így van. Az évezredeket átélt nagycsaládi szervezet létét - amely elsősorban gazdasági közösség volt, és nem vérségi - a honfoglalás korában és az Árpád-korban még csak megkérdőjelezni sincs okunk. Hogy miért nincs, arra a fent elmondottak talán választ adnak.

Nem vehetem itt sorra Kovács László javaslatának minden pontját és teljes érvrendszerét. A javasolt temetőtípusokkal kapcsolatban még csak azt említem meg, hogy talán nem kellene külön csoportba sorolni azokat a temetóinket, ahol a sírok tömbjétól bizonyos távolságra egy vagy több sírra bukkantak. ${ }^{44}$ Ezekben az esetekben ugyanis meg kellene vizsgálni, hogy a közösség temetőjének határán kívül nem hiedelmi okok miatt temettek-e el bizonyos egyéneket, amint az sok helyen előfordult. ${ }^{45}$ Ebben az esetben ugyanis magukat a temetőket nem indokolt külön csoportba sorolni.

Végezetül megismétlem, hogy a címben feltett kérdésre magam csak nemleges választ adhatok. Ez azonban semmiképpen nem csökkenti Kovács László dolgozatának magas tudományos színvonalát és értékét, hiszen a szóban forgó temetők kategorizálásával olyan merész kísérletbe fogott, amire csak kevesen vállalkoztak és vállalkozhattak. Főként azért, mert e kísérlet kapcsán elengedhetetlen az egykori magyar társadalom szerkezetének, szokásainak beható ismerete, amitól még eléggé távol állunk. Sokszor mondjuk és írjuk is, hogy a temető a holtak faluja, ám éppen azt nem tudjuk pontosan, hogyan és mennyire felel meg egymásnak a kettő. Mindenesetre nem kell túlságosan szégyenkeznünk: másutt sem sokkal jobb a helyzet. ${ }^{46}$ Így aztán jobbára sötétben tapogatózunk, hipotéziseket alkotunk, amelyek - amikor szembesítjük óket a valósággal többnyire tévesnek bizonyulnak. Elsősorban talán azért van ez így, mert az egykori magyar társadalom rendkívül sokszínú volt, főként az a szabad középréteg, amelynek temetőiről a fentiekben szót ejtettünk. A kutatás jelen állapotában talán nem lenne szégyen kimondanunk: nem vagyunk még abban a helyzetben, hogy a siker reményében nekiláthatnánk egy ilyen, pontosságra törekvő kategorizálásnak.

43 KovÁCs 2013, 523-524.

44 KovÁCs 2013, 514.

45 Szabó 1976; Fodor 1982, 313-314.

46 A német kutatás hasonló töprengéseiről ld. HoFMANN 2013. 


\section{IRODALOM}

ALI KHAN, IBRAHIM

1930 Turkesztán állattenyésztése, különös tekintettel a földrajzi viszonyokra (Die Viehzucht Turkestan's, mit besonderer Beachtung der geographischen Beziehungen). Földrajzi Közlemények (Budapest) 58, 9-22, 42-44.

BALASSA IVÁN-Ortutay GYULA 1979 Magyar néprajz. Budapest.

BÓNA ISTVÁN

1997a A honfoglaló magyarság régészeti hagyatékának társadalomtörténeti tanulságai. Magyar Tudomány (Budapest) 12, 1451-1461.

1997b Die Archäologie in Ungarn und die ungarische Landnahme. Acta Archaeologica Academiae Scientiarum Hungaricae 49, 345-362.

BRØNDSTED, JOHANNES

1983 A vikingek. Budapest.

CSAlog Zsolt

1967 A IX-XI. századi magyarság gazdálkodásának és életmódjának kérdéséhez (Некоторые вопросы хозяйства и быта венгров IX-XI веков). Agrártörténeti Szemle (Budapest) 9, 228-240.

1969 Zum Nomadismus der landnehmenden Ungarn. In: Földes, L. (Hrsg.): Viehwirtschaft und Hirtenkultur. (Ethnographische Studien.) Budapest, 186-198.

CSEH ISTVÁN

1976 A nagycsalád-rendszer emléke a szlavóniai magyaroknál (The Memories of the Large Family-System in a few Villages in Slavonia). Néprajz és Nyelvtudomány (Budapest) 19-20, 53-81.

CSERNYECOV, VALERIJ N. / ЧЕРНЕцОВ, ВАЛЕРИй H.

1949 Adalékok az obi-ugorok nemzetségi szervezetéhez. Budapest.

DiENES ISTVÁN

1974 [Hozzászólás Balassa Iván előadásához.] Ethnographia (Budapest) 85, 587-591.

ECSEDY ILDIKÓ

1974 Törzs és törzsi társadalom a VI. századi türk birodalomban. Keletkutatás 1973. Budapest, 65-83.

FEHÉR, GÉZA

1959 Zur Geschichte der Steppenvölker von Südrussland im 9.-10. Jh. Studia Slavica Academiae Scientiarum Hungaricae (Budapest) 5, 257-326.

FieLSZTRUP, FJODOR A. / ФИЕЛЬСТРУП, ФЁдОР А.

1927 Скотоводство и кочевание в части степного Западного Казахстана. In: Руденко, С. И. (Ред.): Казаки.

FODOR ISTVÁN

Антропологические очерки. Ленинград, 78-107.

1973 Honfoglalás kori múvészetünk iráni kapcsolatainak kérdéséhez (On the Problem of the Influence of Iranian Art upon Hungarian Art in the Conquest Period, 10th Century). Archaeologiai Értesító (Budapest) 100, 32-41.

1975 A finnugor régészet fő kérdései. In: Hajdú P. (szerk.): Uráli népek. Nyelvrokonaink kultúrája és hagyományai. Budapest, 47-75.

1982 In Search of a New Homeland. The Prehistory of the Hungarian People and the Conquest. Budapest.

1992 A magyarság születése. Magyarország Krónikája. Budapest.

2001 László Gyula, a régész. In: Balassa I.-László E. (szerk.): László Gyula (1910-1998) emlékkönyv. Budapest, 147-270.

2002 Changes in the Hungarian Economy during the Tenth Century. In: Papp, K.-Barta, J. (eds): The First Millennium of Hungary in Europe. Debrecen, 18-37.

2006 A magyar gazdálkodás változásai a 10. században (Die Veränderungen der ungarischen Wirtschaft im 10. Jahrhundert). In: Fodor I.-Szatmári I. (szerk.): A fénylő középkor. Tanulmányok Kovalovszki Júlia tiszteletére. Budapest-Békéscsaba, 13-33.

2013 A kunok gazdálkodásáról. In: Mészáros M. (szerk.): Jászkunság kutatása 2012. Kiskunfélegyháza, 11-15.

2014 A rejtélyes X. század (The Enigmatic 10th Century). Korunk (Kolozsvár) 3/8, 3-11, 125-126.

GYÖRFFY GYÖRGY

1970 A honfoglaló magyarok települési rendjéról (Über das Siedlungssystem der landnehmenden Ungarn).

GYÖRFFY ISTVÁN Archaeologiai Értesítő 97, 191-242.

1943 Magyar falu - magyar ház. Budapest. (Reprint: Budapest 1987.)

HaZANOV, ANATOLI M. / ХАЗАНOB, АНАТОЛИЙ М.

1975 Социальная история Скифов. Москва.

HOFMANN, KeRsTin P.

2013 Gräber und Totenrituale: Zu aktuellen Theorien und Forschungsansätzen. In: Eggert, M. K. H.-Veit, U. (Hrsg.): Theorie in der Archäologie: Zur jüngsten Diskussion in Deutschland. Münster, 269-298. 
HOLL IMRE

1979 Sarvaly középkori lakóházai (Die mittelalterlichen Wohnhäuser von Sarvaly). Archaeologiai Értesítő (Budapest) 106, 33-51.

KhaZanov, Anatoly M. / ХАзанов, Анатолий M.

1984 Nomads and the outside world. Cambridge.

Kós KÁROLY

1972 A nemzetségi szervezet nyomai Rákosdon. In: Uő.: Népélet és néphagyomány. Bukarest.

1976 Tájak, falvak, hagyományok. Bukarest.

KOVÁCS LÁSZLó

2013 A Kárpát-medence honfoglalás és kora Árpád-kori szállási és falusi temetői. Kitekintéssel az előzményekre. Vázlat (Die landnahmezeitlichen und frühárpádenzeitlichen Gräberfelder von Quartieren und Dörfern mit Hinblick auf die Forschungsgeschichte. Ein Abriss). In: Révész L.-Wolf M. (szerk.): A honfoglalás kor kutatásának legújabb eredményei. Tanulmányok Kovács László 70. születésnapjára. Szeged, 511-604.

KRADER, LAWRENCE

1963 The Social Organization of the Mongol-Turkic Nomads. The Hague.

LÁSZLó GYULA

1944 A honfoglaló magyar nép élete. Budapest.

1958 Bestattungsbräuche der landnehmenden Magyaren. Régészeti Dolgozatok - Dissertationes Archaeologicae (Budapest) 1, 83-93.

MESTERHÁZY KÁROLY

1998 Társadalmi struktúrák régészeti vizsgálata (Die archäologische Untersuchung der gesellschaftlichen Strukturen). In: Novák L. (szerk.): Az Alföld társadalma. Az Arany János Múzeum Közleményei 8. Nagykőrös, 19-45.

MNyÉSz

1962 A magyar nyelv értelmező szótára 6. Budapest.

PÁlócZi Horváth ANDRÁs

2014 Keleti népek a középkori Magyarországon. Besenyők, kunok és jászok múvelődéstörténeti emlékei. Budapest.

PenAVIn Olga

1973 Szlavóniai kisszótár. Utószó. In: Penavin O. (szerk.): Szlavóniai hétköznapok. Újvidék, 185-265.

1981 A nagycsaládszervezet Szlavóniában (Kórógyon). Újvidék.

PoljaKov, PAVEl Sz. / Поляков, ПАвел C.

1980 Историческая этнография Средней Азии и Казахстана. Москва.

PotAPOV, LeONYID P. / ПотАПов, ЛЕОНи́д П.

1966 Очерки этнографии тувинцев бассейна левобережья Хемчика. In: Потапов Л. П. (Ред.): Труды Тувинской

RÉVÉSZ LÁSZLó комплексной археолого-этнографической экспедиции II. (1960-1966). Москва-Ленинград, 13-55.

1991 Voltak-e nagycsaládi temetői a honfoglaló magyaroknak? (Über die Existenz der großfamiliären Gräberfelder bei den landnehmenden Ungarn.) Móra Ferenc Múzeum Évkönyve (Szeged) 1984-1985/2, 615-639.

2003 A bezdédi honfoglalás kori temető. Egy régészeti fikció nyomában. In: Istvánovits E.: A Rétköz honfoglalás- és Árpád-kori emlékanyaga. Budapest, 432-440.

SELMECZI LÁSZLÓ

1992 Régészeti-néprajzi tanulmányok a jászokról és a kunokról. Folklór és Etnográfia 64. Debrecen.

2011 Kötöny népe Magyarországon. Karcag.

Silov, Valentij P. / Шилов, ВALENTий П.

1975 Очерки по истории древних племен Нижнего Поволжья. Ленинград.

SZABÓ ISTVÁN

1966 A falurendszer kialakulása Magyarországon (X-XV. század). Budapest.

SZABÓ JÁNOS GYŐZŐ

1976 Árpád-kori telep és temetője Sarud határában, III. (Eine Siedlung und deren Friedhof aus der

SZABÓ LÁSZLÓ Árpádenzeit bei Sarud, III). Egri Múzeum Évkönyve (Eger) 14, 17-89.

TESz

1980 A rokonsági rendszer Magyarországon. Studia Folkloristica et Ethnographica 4. Debrecen.

1976 Benkő L. (szerk).: A magyar nyelv történeti-etimológiai szótára 3. Budapest.

TOCIK, ANTON

1968 Altmagyarische Gräberfelder in der Südwestslowakei. Archaeologia Slovaca - Catalogi III. Bratislava.

VAJNSTEJN, SZEVJAN I. / ВАЙНШТЕЙН, СЕВЬЯН И.

1972 Историческая этнография тувинцев. Москва. 


\section{WERE THERE "NOMADIC CAMPSITE CEMETERIES" IN HUNGARY DURING THE 10TH-12TH CENTURIES?}

\section{ISTVÁN FODOR}

In a recent study, L. Kovács proposed a classification of the non-churchyard cemeteries of the 10th-12th centuries (KovÁcs 2013). In his view, these cemeteries represented burial grounds used by sedentary communities living in agrarian villages and by the population of nomadic summer and winter settlements. He argued that a major portion of the ancient Hungarian population was engaged in nomadic stockbreeding during this period and that the majority of the relatively small burial grounds containing less than a hundred burials can be associated with this population. However, Kovács has disregarded the fact that a significant portion of the ancient Hungarians had been sedentary already in their eastern lands (Levedia and Etelköz) before the Conquest of 895 . The ecological conditions in the Carpathian Basin were largely unsuitable for an eastern-type nomadic economy involving movement between campsites, and therefore most of the groups still pursuing a nomadic life-style within the ancient Hungarian population shifted to sedentism already in the 10th century (cp. FODOR 2002). Thus, there were very few "nomadic campsite cemeteries" used by the ancient Hungarians (a term that is historically misleading in itself).

Following I. Bóna's lead (BóNA 1997a), Kovács believes that the cemeteries containing a small number of burials cannot be interpreted as the burial grounds of extended families as earlier suggested by Gy. László (LÁsZLó 1944; 1958). According to Bóna and Kovács, these cemeteries were burial grounds used by warriors of military stations that resembled Viking ones. However, the military organisation of the ancient Hungarians differed substantially from the Viking one because it had a steppean nomadic origin. Moreover, military camps of the type established by the Vikings are wholly unknown in Hungary. The assumption that the ancient Hungarian cemeteries containing few burials were the resting places of kindreds is also wholly mistaken and rests on a misunderstanding of the structure of kindreds and extended families.

The basic social unit of the ancient Hungarians was the nuclear family, although there were also extended families. The latter can be demonstrated among the ancestors of the Hungarians, from the 2nd millennium BC to the modern period. There are known cases when one generation of an extended family used a separate burial ground, one example being the Tiszabezdéd cemetery that was used by one generation of an extended family. However, this practice was extremely rare. The kindreds of the 10th century did not have separate cemeteries, except for the families of their leaders.

The small cemeteries of the 10th-11th centuries were the resting places of the middle social class of ancient Hungarian society. This layer was extremely heterogeneous and it is virtually impossible to distinguish the groups interring their dead in these burial grounds from one another. 